\title{
Socio, Economic and Cultural Impact of Soap Operas on Home Makers (A Study in Andhra Pradesh)
}

\section{Anitha $\mathbf{K}^{*}$}

Department of Communications and Journalism, Osmania University, Hyderabad, Andhra Pradesh, India

\begin{abstract}
Soap operas have gained huge popularity all over the world and women are an important component of these soap operas. Contemporary soap operas' content are mostly dominated by family dramas and house-hold fights. In the process of attracting more female audiences, soaps are presenting values that are different from reality. Various studies conducted on the influence of soap operas on viewer' attitudes, indicate the growing popularity of soaps all over the world but at the same time it is also important to study the way the content is portrayed in these soaps, particularly in India where socio-cultural values influence the lives of individuals. Portrayal of negative content in soaps can influence the society in a negative way. Socio-cultural values are mostly depicted negatively in Telugu soap operas of Andhra Pradesh. Therefore, this study seeks to re-examine the portrayal of socio, cultural and economic values in Telugu soap operas and their influence on the housewives of Andhra Pradesh. This study examined the content of four Telugu soap operas by using the content analysis method and also conducted a survey in order to know homemakers' opinions on the patterns of portrayal of values and ideologies in Telugu soap operas. Six districts from Andhra Pradesh were randomly selected for survey with a sample size of 300 homemakers. The study is based on the Cultivation Theory. The findings obtained through content analysis of Telugu soaps suggest that the socio, cultural and economic values in majority of serials are portrayed negatively; soaps are mainly focusing on promoting the ideology of radical feminism in the portrayal of its female characters. The data obtained through the survey indicates that soap opera audiences are not passive, they are critical about the content particularly the portrayal of the socio-cultural values and viewers are not influenced by such negative portrayal but a perception shared by a selection is that there is a likelihood of some audience being influenced by such portrayal.
\end{abstract}

Keywords: Social- cultural and economic values influence; Telugu soap-operas; Impact; Attitudinal change; Radical feminism; Homemakers

\section{Introduction}

Soap operas have become a part and parcel of the lives of so many viewers all over the world. The popularity of this genre is ruling the Television Industry globally, nationally and locally. The history of soap opera can be traced back to the 1800s when novels such as Dickens appeared in newspapers in serialized formats (Kielwasser \& Wolf) [1]. This' episodic format conformed...to melodramatic requirements' (Gledhill) [2]. In USA, soap operas began as serialized dramas on radio and later soaps entered television as 'serialized daytime dramas which were broadcast daily'. Originally directed at women, soap operas functioned as a vehicle for advertising. The term 'soap' gained from its association with advertising of soap products (Brown and Barwick, Gledhill,) [3].

A crucial element that defines soap opera is the open-ended nature of the narrative, with stories spanning several episodes. The defining feature that makes a television program a soap opera, according to Albert Moran, is "that form of television that works with a continuous open narrative. Each episode ends with a promise that the storyline is to be continued in another episode".

The first televised soap opera was 'Peyton Place', which ran from 1964-69 and eventually appeared on British TV. Despite the success of the soap operas in America, Britain did not take them seriously at all. One reason for this can be because BBC was a Public Service Broadcast and was financed by the license fee and not by advertising. The other reason was BBC was led by a man called John Reith who felt that television should provide programmes of 'culture' (to better them and broaden their education) and soap operas were not considered culture. But later, slowly the craze for soap operas developed not only in UK, but even in Australia, New Zealand, Canada and all over the world.

Indian soap operas do not lag behind in their attempt of attracting women audience with new and unique storylines. This saga of success of soap operas in India started with 'Hum Log' in 1980 and is still continuing with increasing popularity all over the country. Though in India patriarchal families dominate the society, the role of women is considered vital with issues related to the practice of culture and carrying the values to the next generations. Contemporary soap operas' content is mostly dominated by family dramas and house hold fights to attract the women audience. In the process of attracting more female audiences soaps are presenting the values differently from reality. It is essential to know the way the content is portrayed in these soaps particularly in India where socio-cultural values influence the life of individuals. Portrayal of negative content in soaps can influence the society in a negative way. There is huge loyal fan following for soap operas even in Andhra Pradesh. Therefore, most of the Northern soap operas are making their entry in to the Telugu market by dubbing serials in order to entertain the Andhra audience. The fight between the dubbed soap operas and the local soap operas is showing its effect on the content of Telugu soaps enormously.

${ }^{*}$ Corresponding author: Anitha K, Ph. D. Scholar, Dept. Of Communications and Journalism, Osmania University, Hyderabad, Andhra Pradesh, India, Tel: 9581448824; E-mail: placements.anitha@gmail.com

Received April 29, 2014; Accepted May 16, 2014; Published May 27, 2014

Citation: Anitha K (2014) Socio, Economic and Cultural Impact of Soap Operas on Home Makers (A Study in Andhra Pradesh). J Mass Communicat Journalism 4: 189. doi:10.4172/2165-7912.1000189

Copyright: (c) 2014 Anitha K. This is an open-access article distributed under the terms of the Creative Commons Attribution License, which permits unrestricted use, distribution, and reproduction in any medium, provided the original author and source are credited. 


\section{Literature Review}

Many studies have been conducted globally and nationally to study the impact of soap operas on different categories and age groups of audiences. But limited studies have been conducted on the impact of socio-economic and cultural values of soap operas on audience. Particularly, there are a very less number of studies done on Telugu soap operas of Andhra Pradesh. The ROL presented here starts with international studies, then national and towards the end local studies on Telugu soap operas. Important studies worth mentioning have been selected to present here.

Karaj [4], in his study on "Wonder Women: The Portrayal of Women in Television Soap operas", explores the depiction of women in soap operas aired during the fall of 2000.Content analysis method was used for this study. Variables of the study were marital status; employment and age of female character were compared to male character, as well as to the general population. The researcher also tried to study portrayal of single mother hood, family support and socioeconomic status. The study's findings supported the researcher's hypotheses that women in soap operas would be young, single, upperclass professionals. The researcher identified that skewed portrayal could lead women to feel misrepresented or to become dissatisfied with their lives.

Robert Jensen [5] studied on "Cable Television and Women's Status in India" and explored that the introduction of cable television is associated with significant decreases in the reported acceptability of domestic violence towards women and son preference, as well as increases in women's autonomy and decreases in fertility. They also found suggestive evidence that exposure to cable increases school enrollment for younger children, perhaps through increased participation of women in household decision-making.

Shoma Munshi's [6] in her book "Prime Time Soap Operas on Indian Television" is the first of its kind to examine prime time soap operas on Indian television. It examines five prime time soaps, and argues that this particular genre of popular culture provides important resources for insights into contemporary social issues and practices. Focusing on the complex constructions of family, tradition, 'Indianness' and gender, she also analyses narrative structures of soaps in the context of their fractured and never-ending time frames and plot outlines.

Varsha A. Sherring [7] studied on "Indian Pro-social Soap Operas as Cultural Carriers". This study deals with finding the links, if any, between social and personal identity of Indian women, and the effects of Indian pro-social soap operas in forming mind sets affecting attitudes and actions relating to the two major social evils still existing in modern Indian society, and highlighted here in: female feticide and child marriage

Anita Nagulapalli of CMS Media Lab in collaboration with Padmaja Shaw [8] of the Department of Communication and Journalism, Osmania University, undertook an intensive study of Telugu daily serials to analyse the violence depicted in them. A secondary objective of the study was also to see the kind of advertising support such programming is receiving.

The study analyzed 144 episodes, 36 each from ETV, ZEE Telugu, Gemini, MAA shown in three primetime slots: 7.30-8.00 PM, 8.008.30 PM and 8.30-9.00 PM during August, September and October of 2012. The study measured in minutes the violent content in evening prime-time soaps telecast on the four major general entertainment channels in Telugu: ETV, Zee Telugu, Gemini and Maa. Out of 144 episodes studied, there were 282 violent events or acts. Of the four channels showing daily serials on prime time, ETV with $34 \%$ has shown the highest number (96) of violent events. The second highest of $24 \%$ (68) was shown on Maa TV, with Zee showing $22 \%$ (64) and Gemini showing $19.4 \%$ (54) each. Significantly, the data shows that it is women who predominate as both victims and perpetrators of violence, while men are fewer compared to women even among negative characters. It is also significant that men are also shown as victims of violence. Women playing both positive and negative roles are shown as both perpetrators and victims. Violence as a mode of interaction is normalized and women are shown using this mode persistently.

\section{Significance of the Study}

The popularity of soaps has become impossible to ignore. It becomes interesting to know why so many women enjoy them.Studies conducted on the influence of soap operas on viewer's attitudes indicate the growing popularity of soaps all over the world, but at the same time it is also significant to study the way the content is portrayed in these soaps, particularly in India where socio-cultural values influence the lives of individuals. Portrayal of negative content in soaps can influence the society in a negative way. Socio-cultural values are mostly depicted negatively in Telugu soap operas of Andhra Pradesh. Taking this as the strong point the researcher set out to study the impact of soap opera, because it is popular and is supposed to carry important socio-cultural values: it is for and about women, it is not prestigious, and the researcher wanted to discover why it gives pleasure to millions of people and to relate that insight to the practice of socio-cultural values in their daily life. Soap's' representation of women invite a serious challenge. And this naturally, needs a reexamination of these soap operas in relation to socio--economic and cultural values.

\section{Hypothesis}

- Broken relationships in the family are portrayed more frequently in the Telugu soap operas.

- Disrespect towards Traditional values is portrayed more in Telugu soap operas.

- The female characters of Telugu soap operas are portrayed more in stereotyped gender roles.

- Frequency of anti-social activities like murder, rapes etc... are very high in Telugu soap operas.

\section{Aim}

The primary aim of the study is to evaluate the impact of Social, Cultural and Economic values of Telugu soap operas on the Homemakers of Andhra Pradesh. It includes the evaluation of the nature and content of the Telugu soap operas in relation to the portrayal of social, cultural and economic values and viewers' perceptions.

\section{Objectives}

- To identify and analyze the content/nature of various serials telecast in different television channels

- To examine the portrayal of socio-cultural values in these serials

- To find out perceptions of homemakers on Socio- Cultural values of Telugu serials and impact of these values on homemakers 
- To identify the economic aspects and their influence on the soap opera viewers

- To find out the advertisements which are telecast along with the daily soaps

\section{Research Approach-Qualitative and Quantitative}

The researcher adopted the method of quantitative and qualitative content analysis of Telugu soap operas and a survey to obtain the results of set objectives. Four top rated Telugu soap operas of the year 2010 have been selected for the purpose of content analysis. The selection of episodes for quantitative content analysis has been done randomly on the basis of availability of videos on YouTube. Mogalirekullu, Muddubidda, Chandramukhi serials have completed more than 1500 episodes, so the researcher has randomly selected 150 episodes from these three serials whereas Anna Chellellu has completed only 500 episodes, therefore only 50 episodes have been selected for the analysis. Each event was measured in time from the beginning of the sequences to its end, generally constituting characters continuity, location continuity, idea continuity or all of them. Social, cultural and economic values are further divided into sub--categories such as family relations, cultural values, economic issues and portrayal of violence. Sample size for the survey was 300 home makers from six randomly selected districts from Andhra Pradesh, and the age group of the sample is above 25 years. The data was analyzed by using descriptive statistics with the help of SPSS. There are two variables for the study, one is independent and the other is dependent. The independent variables are T.V. soap operas, age, gender and nature of work and the dependent variables are values such as family relationships, tradition, customs, anti-social elements, spendthrift and urban lifestyle. Statistical procedures were used to draw associations between the independent and dependent variables and conclusions were drawn.

\section{Scope and Limitations}

Researcher used purposive sample for this study which invites the problem of external validity. So the results of this study cannot be generalized across the entire population of AP. The study is an attempt to provide a broad way to explain the phenomenon, which was not deep enough. Due to limitation of resources, this study used a limited sample and was subjected only to homemakers.

\section{Data Analysis and Interpretation}

\section{Quantitative content analysis}

This part of the data analysis section, presents the data obtained through quantitative content analysis. The tables indicate the time allotted for values in selected serials (Tables 1-4). The table presents the time allotted for different values in seconds and even in percentages. Socio-cultural values are allotted the highest percentage of time in all the selected soaps (Mogalirekullu-68\%, Chandramuki-53\%, Muddubidda-62\% and Anna Chellellu-62\%) and the content related to violence takes next position (Mogalirekullu-30\%, Chandramuki- $40 \%$, Muddubidda-32\% and Anna Chellellu-23aspects were allotted less time when compared with the other two categories(Mogalirekullu-2\%, Chandramuki-4\%, Muddubidda-6\% and Anna Chellellu-15\%) [9-14].

The table below presents the percentages of the quantitative data obtained from content analysis of the four selected soap operas.

\section{Qualitative content analysis}

In the qualitative content analysis it is observed that although the percentage of socio-cultural values is more in soaps, most of the time these values are portrayed negatively. For instance, fights between family members for property, for revenge taking and for love affairs are shown very frequently. Few important relationships like mother-in-law and daughter-in-law, husband and wife are always fighting for some family issues. Values like respecting elders, affection among other family members, and helping each other, are missing in order to increase the tension among viewers to grab their attention. Disrespectful language used by the male and female characters of these serials is found commonly in all the soaps. It is also portrayed as though

\begin{tabular}{|l|l|l|l|l|l|l|}
\hline Soap opera & Duration of each Episode & No. of Episodes & Total Seconds & Socio-cultural values & Economic aspects & Violence \\
\hline Mogalirekullu & $\begin{array}{l}1080 \\
\text { seconds }\end{array}$ & 150 & $\begin{array}{l}1,62,000 \\
\text { seconds }\end{array}$ & $\begin{array}{l}1,09,668 \\
\text { seconds }\end{array}$ & $\begin{array}{l}\text { Violence } \\
48,723 \\
\text { Seconds }\end{array}$ \\
\hline Percentage & & & $100 \%$ & $68 \%$ & $2 \%$ \\
\hline
\end{tabular}

Table 1: Time allotted for value in Mogalirekullu soap opera.

\begin{tabular}{|c|c|c|c|c|c|c|c|}
\hline Soap opera & Duration of each Episode & No. of Episodes & Total Seconds & Socio-cultural values & Economic aspects & comedy & violence \\
\hline Chandramuki & $\begin{array}{l}1200 \\
\text { seconds }\end{array}$ & 150 & $\begin{array}{l}1,80,000 \\
\text { seconds }\end{array}$ & $\begin{array}{l}95,500 \\
\text { Seconds }\end{array}$ & $\begin{array}{l}7920 \\
\text { Seconds }\end{array}$ & $\begin{array}{l}4500 \\
\text { seconds }\end{array}$ & $\begin{array}{l}72,080 \\
\text { Seconds }\end{array}$ \\
\hline Percentage & & & $100 \%$ & $53 \%$ & $4 \%$ & $3 \%$ & $40 \%$ \\
\hline
\end{tabular}

Table 2: Time allotted for value in Chandramuki soap opera.

\begin{tabular}{|l|l|l|l|l|l|}
\hline Soap opera & Duration of each Episode & No. of Episodes & Total Seconds & Socio-cultural values & Economic aspects \\
\hline Muddubidda & $\begin{array}{l}1080 \\
\text { seconds }\end{array}$ & 150 & $1,62,000$ seconds & $\begin{array}{l}1,00,000 \\
\text { Seconds }\end{array}$ & $\begin{array}{l}10,300 \\
\text { Seconds }\end{array}$ \\
\hline Percentage & & & $100 \%$ & $62 \%$ & $6 \%$ \\
\hline
\end{tabular}

Table 3: Time allotted for each category of value in Muddu Bidda.

\begin{tabular}{|c|c|c|c|c|c|c|}
\hline Soap opera & Duration of each Episode & No. of Episodes & Total Seconds & Socio-cultural values & Economic aspects & violence \\
\hline Anna Chellellu & $\begin{array}{l}1080 \\
\text { seconds }\end{array}$ & 50 & $\begin{array}{l}54,000 \\
\text { seconds }\end{array}$ & $\begin{array}{l}33,798 \\
\text { seconds }\end{array}$ & $\begin{array}{l}7,884 \\
\text { seconds }\end{array}$ & $\begin{array}{l}12,318 \\
\text { seconds }\end{array}$ \\
\hline Percentage & & & $100 \%$ & $62 \%$ & $15 \%$ & $23 \%$ \\
\hline
\end{tabular}

Table 4: Time allotted for each category of value in seconds in Anna Chellellu. 
family members quite often address each other with objectionable/ vulgar language.

The frequency of violence is observed as excess in soap operas. Verbal violence is identified daily, like threatening to kill someone, warnings, blackmails, harassments etc...Whereas every week at least one or more murders in action are portrayed in soaps. Economic aspects like urban life style is a common feature found in all the soaps, the characters' attires do not match with the context in which the artist is acting. This is giving mostly unrealistic appeal.

Finally, it is observed that social, cultural and economic values found in soap operas are mostly portrayed as negative. And the time allotted for such negative values is more than the positive values, the frequency of the negative content is double than the positive content of a five day soap per week.

\section{Survey}

This section gives the opinion of the homemakers from the six selected districts on the portrayal of socio-cultural and economic values and their influence on their daily lives. The tables here give the clear understanding of the data obtained to achieve the set objects of the study.

General Profile of the sample: A vast majority of respondents (83\%) are between the age group of 25 to 45 years. In the sample an overwhelming $(93.7 \%)$ respondents watch fiction based programmes like daily serials regularly. Half of the respondents (49.7\%) in the study like the content of Mogalirekullu soap opera than the other three serials selected for the study.

Table 5 shows that the majority of the respondents (42.7\%) are neutral about the portrayal of the socio-cultural values of soap operas, whereas few respondents (38\%) felt the values are mostly negative, (19.3\%) respondents think positively. This table indicates the Portrayal Socio-cultural values.

\section{Economic aspects}

The survey data indicates that homemakers like to watch luxury and glamour portrayed in soaps but majority of respondents $(77.7 \%)$ are not economically motivated to buy the attractive furniture and jewelry shown in soaps, few respondents(21.0\%)said that they get motivated to buy those items, while very less respondents (1.3\%)sometimes get motivated, but not always (Table 6)

\section{Portrayal of violence}

Anti-social activities like smoking, drinking, kidnapping, rapes and violence are shown quite often than religious methods like pooja, prayers etc respondents (49\%) said these anti-social elements are seen daily and some respondents (40\%) said it is moderate.(11\%)

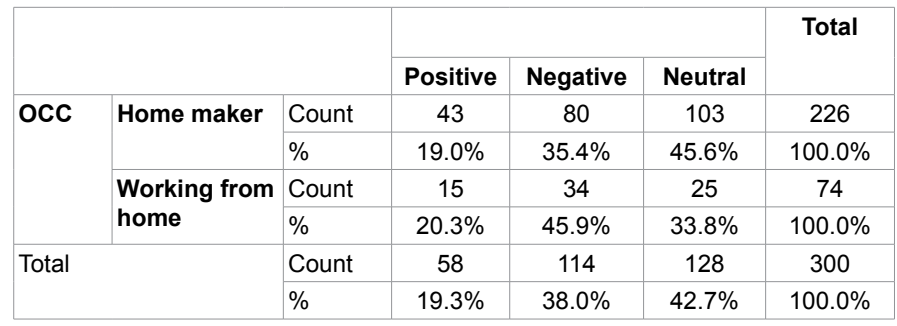

Table 5: Portrayal Socio-cultural values?

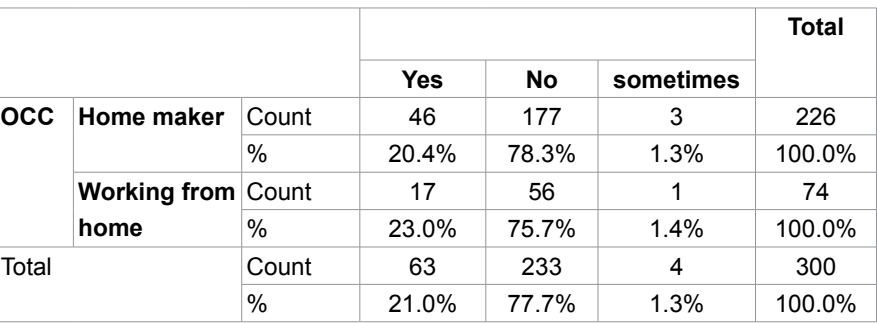

Table 6: Influence of soaps on economic aspects?

\begin{tabular}{|c|c|c|c|c|c|c|}
\hline & \multirow[b]{2}{*}{ Excess } & \multirow[b]{2}{*}{ Is it moderate } & \multirow[b]{2}{*}{ too little } & \multirow[t]{2}{*}{ Total } \\
\hline & & & & & & \\
\hline \multirow[t]{4}{*}{ OCC } & \multirow[t]{2}{*}{ Home maker } & Count & 99 & 98 & 29 & 226 \\
\hline & & $\%$ & $43.8 \%$ & $43.4 \%$ & $12.8 \%$ & $100.0 \%$ \\
\hline & \multirow{2}{*}{$\begin{array}{l}\text { Working } \\
\text { from home }\end{array}$} & Count & 48 & 21 & 5 & 74 \\
\hline & & $\%$ & $64.9 \%$ & $28.4 \%$ & $6.8 \%$ & $100.0 \%$ \\
\hline \multirow[t]{2}{*}{ Total } & & Count & 147 & 119 & 34 & 300 \\
\hline & & $\%$ & $49.0 \%$ & $39.7 \%$ & $11.3 \%$ & $100.0 \%$ \\
\hline
\end{tabular}

Table 7: Frequency of Anti-social elements?

respondents felt such portrayal is very less (Table 7).

\section{Advertisements during soap operas}

Advertisements are the main source of revenue for soaps and for the channel owners as well, but most of the viewers are not interested to watch them. Very few viewers, who are interested, prefer to watch health related advertisements than kitchen related ads. The table below indicates the same (Table 8 ).

\section{Testing of Hypotheses}

This research study is conducted on the basis of four hypotheses.

Hypothesis 1: Broken relationships in the family are portrayed more frequently in the Telugu soap operas.

The age-wise obtained data indicates the statistical significant results, in aspects related to broken family relationships in soap operas, like influence of negative values on viewers, second and more marriages in soaps, stereotyping women in soaps, no content on women empowerment and realism in soaps.

Hypothesis 2: Disrespect towards Traditional values is portrayed more in Telugu soap operas.

The location-wise obtained data indicates the statistically significant results, in aspects related to disrespect towards traditional values in soap operas, like portrayal of less cultural and traditional values, frequency of anti-social activities.

Hypothesis 3: The female characters of Telugu soap operas are portrayed more in stereotyped gender roles.

The age, location-wise obtained data indicates the statistical significant results, in aspects related to stereotyping women in soaps, no content on women empowerment, gender discrimination in soaps, portrayal of female villains.

Hypothesis 4: Frequency of anti-social activities like murder, rapes etc are very high in Telugu soap operas.

The age, location and occupation-wise obtained shows the statistical significant results, in aspects related to high frequency of anti-social activities in soap operas. 


\begin{tabular}{|c|c|c|c|c|c|c|c|c|c|c|}
\hline & & & \multirow[b]{2}{*}{ Beauty } & \multirow[b]{2}{*}{$\begin{array}{c}\text { Kitchen related } \\
\text { products }\end{array}$} & \multirow[b]{2}{*}{ Furniture } & \multirow[b]{2}{*}{$\begin{array}{l}\text { Food } \\
\text { items }\end{array}$} & \multirow[b]{2}{*}{ Vehicles } & \multirow[b]{2}{*}{$\begin{array}{l}\text { Health/ } \\
\text { Hygiene }\end{array}$} & \multirow[b]{2}{*}{$\begin{array}{l}\text { No special } \\
\text { preferences }\end{array}$} & \multirow[t]{2}{*}{ Total } \\
\hline & & & & & & & & & & \\
\hline \multirow[t]{12}{*}{ Location } & \multirow[t]{2}{*}{ HYD } & Count & 3 & 9 & 0 & 4 & 1 & 20 & 13 & 50 \\
\hline & & $\%$ & $6.0 \%$ & $18.0 \%$ & $0.0 \%$ & $8.0 \%$ & $2.0 \%$ & $40.0 \%$ & $26.0 \%$ & $100.0 \%$ \\
\hline & \multirow[t]{2}{*}{ KDP } & Count & 2 & 16 & 8 & 10 & 1 & 11 & 2 & 50 \\
\hline & & $\%$ & $4.0 \%$ & $32.0 \%$ & $16.0 \%$ & $20.0 \%$ & $2.0 \%$ & $22.0 \%$ & $4.0 \%$ & $100.0 \%$ \\
\hline & \multirow[t]{2}{*}{ MDK } & Count & 5 & 7 & 7 & 2 & 0 & 23 & 6 & 50 \\
\hline & & $\%$ & $10.0 \%$ & $14.0 \%$ & $14.0 \%$ & $4.0 \%$ & $0.0 \%$ & $46.0 \%$ & $12.0 \%$ & $100.0 \%$ \\
\hline & \multirow[t]{2}{*}{ NLR } & Count & 4 & 15 & 16 & 2 & 2 & 7 & 4 & 50 \\
\hline & & $\%$ & $8.0 \%$ & $30.0 \%$ & $32.0 \%$ & $4.0 \%$ & $4.0 \%$ & $14.0 \%$ & $8.0 \%$ & $100.0 \%$ \\
\hline & \multirow[t]{2}{*}{ TPT } & Count & 12 & 6 & 8 & 1 & 3 & 16 & 4 & 50 \\
\hline & & $\%$ & $24.0 \%$ & $12.0 \%$ & $16.0 \%$ & $2.0 \%$ & $6.0 \%$ & $32.0 \%$ & $8.0 \%$ & $100.0 \%$ \\
\hline & \multirow[t]{2}{*}{ VSP } & Count & 5 & 6 & 10 & 3 & 0 & 17 & 9 & 50 \\
\hline & & $\%$ & $10.0 \%$ & $12.0 \%$ & $20.0 \%$ & $6.0 \%$ & $0.0 \%$ & $34.0 \%$ & $18.0 \%$ & $100.0 \%$ \\
\hline \multirow{2}{*}{\multicolumn{2}{|c|}{ Total }} & Count & 31 & 59 & 49 & 22 & 7 & 94 & 38 & 300 \\
\hline & & $\%$ & $10.3 \%$ & $19.7 \%$ & $16.3 \%$ & $7.3 \%$ & $2.3 \%$ & $31.3 \%$ & $12.7 \%$ & $100.0 \%$ \\
\hline
\end{tabular}

Table 8: Kind of advertisements viewers like to watch during break time

Table 8 indicates that (31\%)of the viewer's' prefer to watchhealth related advertisements, $19.7 \%$ selected kitchen related products advertisements, $16.3 \%$ chose furniture and only $10 \%$ selected beauty related advertisements that are telecast during the break time of the soap operas.

The findings suggest that Telugu soap operas are focusing more on negative socio-cultural values to attract the attention of the viewers. In case of economic aspects viewers are enjoying the portrayal of soaps with glamour and luxurious interiors but are against the portrayal of excess violence in soaps.

\section{Theoretical framework implications}

The effects of Gerbner's mean world syndrome can easily be seen in homemakers in relation to portrayal of violence. Most of the viewers are regular audience of soap operas and watch them for long period of time, every day, without leaving their rooms and do not like any disturbance while viewing the soap operas. Some of the respondents who admitted their addiction to soaps believe what is shown in soaps as true and real. Having only the media to guide their interpretation of the 'real world', few home makers believe that the world is a corrupt and violent place. Gerbner's cultivation theory says that television has become the main source of storytelling in today's society. Those who watch the television for four or more hours a day are labelledas heavy television viewers and those who view less than four hours per day, are light viewers. Heavy viewers are exposed to more violence and therefore are affected by the Mean World Syndrome, an idea that the world is worse than it actually was found true in this research. This study is supporting the statement of Gerbner, that the overuse of television is creating a homogeneous and fearful populace. This study is in convergence with the opinion of Gerbner that although other media have violent content, television violence is the most significant. Gerbner's saying that prime-time programs contained violence or the threat of violence was found true and relevant in Indian soap operas as well and applicable to the Telugu Soap Opera Industry also. As the theory identified women as one among the other groups who are most often the victims of TV violence, the same was proved in this study as the viewer's' said that increase of violence in the real world on women and disrespect towards women is increasing due to soap opera negative content in portrayal of women.

\section{Findings and Results}

A common assumption is that people are highly critical about soap opera content. They are accepting that the soaps have negative content more than positive but are not rejecting them completely, watching and criticizing. In all the areas of research there is a good viewership for soap operas. Most of the soap opera viewers are middle aged homemakers between 25-45 years of age group. Out of the four serials that were selected for the study Mogalirekullu was liked by most of the viewers for its presentation and content in relation to social, cultural, economic values when compared with the other three soaps.

The data obtained through content analysis and survey shows that social values and family relationships are mostly portrayed negatively in Telugu soaps. Family relationships like mother-in-law and daughterin-law, husband and wife and respect towards elders in family and affections among other family members, are mostly portrayed in a negative way to attract the attention of the audience towards the soap and are allotted more time for such content.

Cultural values are mostly misrepresented in all soaps; it is observed in content analysis that disrespectful language by almost all the characters in soaps is a common element. It was also observed that the content writers portray about customs, traditions, respect to God, love and affection between family members, only during festivals and functions and for the rest of the days, the routine family fights and drama continues.

Viewers are attracted to the tactics of soap opera makers to increase TRP's by showing glamorous locations, costly lifestyle, heavy jewellery, lavish spending etc. Portrayal of women in soaps is mostly stereotyped and is sometimes even disrespectful in nature; excess physical and mental violence on women is portrayed. Content on empowerment of women is totally missing in soaps and negative portrayal like female villains, class differences; gender differences dominate most of the soaps.

Advertisements are the main source of revenue for soaps and for the channel owners as well, but most of the viewers are not interested to watch them, in fact they felt it was a disturbance during the show. Very few viewers who watch advertisements prefer to watch health related advertisements more than kitchen and beauty related ads.

\section{Conclusion}

This research study is conducted by the researcher to analyse the 
Citation: Anitha K (2014) Socio, Economic and Cultural Impact of Soap Operas on Home Makers (A Study in Andhra Pradesh). J Mass Communicat Journalism 4: 189. doi:10.4172/2165-7912.1000189

Page 6 of 6

socio, economic and cultural impact of soap operas on home makers of Andhra Pradesh. Keeping in view the objectives of the study the researcher selected four soap operas being telecast in four different Telugu TV channels during 2010. The researcher analysed social, cultural, economic values along with portrayal of women and violence in these soap operas.

The content analysis indicates that a lot of socio-cultural values like family relationships; tradition and customs are misrepresented and are presented negatively in soaps. The data obtained through content analysis and the survey, also indicates the same and observed that viewers are critical about the excess negative content related to values and portrayal of women in Telugu soap operas, a small section of audience raised concern on this negative content in serials and its influence on younger generation and on a small section of homemakers. Whereas economic aspects like urban lifestyle and luxurious spending are enjoyed by women viewers, but such portrayal is not motivating them to buy them in reality.

The following inferences can be drawn based on the data emerging from the content analysis and survey:

- The audience are not passive.

- They are critical about the content, particularly the portrayal of the socio-cultural values.

- Respondents are not influenced by the portrayal, but a perception shared by a section is that there is a likelihood of some people being influenced by such portrayal.

Viewers requested and suggested for positive portrayal of social and cultural values as the women, children and youth are watching soaps and there is every chance of them getting influenced by such negative values in the future.

\section{References}

1. Kielwasser AP, Wolf M A (1989) The appeal of soap opera: an analysis of process and quality in dramatic serial gratifications, Journal of Popular Culture 23: 111-124.

2. Gledhill C (1992) Speculations on the relationship between soap opera and melodrama. Quarterly Review of Film and Video 14: 103-124.

3. Brown ME, Barwick L (1987) Fables and endless genealogies: soap opera and women's culture. Continuum: The Australian Journal of Media and Culture.

4. Karaj W (2000) "Wonder Women: The Portrayal of Women in Television Soap operas".

5. Robert J (2008) The Power of TV: Cable Television and Women Status in India.

6. Shoma M (2009) Prime Time Soap Opera on Indian Television, Routledge India.

7. Varsha AS (2010) Women's Identity shaped by Television in India: A Study on Indian Prosocial soap operas as Cultural Carriers. School of Communication and the Arts, Regent University

8. Nagulapalli A, Shaw P. (2013) Telugu prime time: violence abounds.

9. Gokulsing KM (2003) Soft-soaping India. The World of Indian Televised Soap Operas. Trentham Books Ltd.

10. Etv Network-Home.

11. Zee Telugu Live.

12. Maa TV, Wikipedia.

13. Gemini TV, Wikipedia.

14. Telugutv.info. 